\title{
Integrasi Dan Pengujian Prototipe Sistem Kendali Pada Kendaraan Taktis Water Cannon Sesuai Kebutuhan Polri
}

\author{
Eko Syamsuddin Hasrito ${ }^{1,}$ Dede Santoso ${ }^{1}$, Kuwat Darmanto ${ }^{1}$ dan Agustian ${ }^{2}$
}

\begin{abstract}
ABSTRACK: To gain credibility, a prototype system that controls the Water Cannon that has been developed by BPPT which is supported by PT Astanita Sukses Apindo (ASA) since 2017, then integrates and tests statistics and dynamically with variations in combination with water canon. The integration was carried out by installing a prototype of the Cannon Air control system on a modified AS ASA surveillance vehicle at its factory in Cileungsi, West Java. The test is carried out by statistical means of spraying air to find out the farthest reach from the end of the canon water nozzle, and by means of a dynamic test directing the canon air nozzle at various angles when sprayed with air. This paper explains the stages of integration and testing-validation for the validation of the Rantis Water Cannon certification system according to the operational needs of the National Police. The test results before the Police team. Testing with 1 canon of water obtained the farthest distance of water achievement 55 meters, with 2 canons of water can be obtained a distance of 45 meters. At a distance of 30 meters, a barrel filled with half water was piled on top of two barrels filled with water

Keywords: Canon Air, Integration, Nozzle, Prototype, Rantis, Water Cannon Control System, Reliability Test.
\end{abstract}

ABSTRAK: Untuk menguji kehandalan prototipe sistem kendali Water Cannon yang telah dikembangan BPPT bekerjasama dengan PT Astanita Sukses Apindo (ASA) sejak tahun 2017, maka dilakukan integrasi dan pengujian statis dan dinamis dengan berbagai variasi tembakan dengan canon air. Integrasi dilakukan dengan memasang prototipe sistem kendali Water Cannon pada kendaraan taktis (Rantis) hasil modifikasi PT ASA di pabriknya di Cileungsi, Jawa Barat. Pengujian dilakukan dengan cara statis yaitu penyemprotan air untuk mengetahui jangkauan terjauh dari ujung nozzle canon air, dan dengan cara uji dinamis mengarahkan nozzle canon air dengan berbagai sudut pada saat air disemprotkan. Tulisan ini menjelaskan tahapan-tahapan integrasi dan pengujian-pengujian untuk validasi kemampuan sistem kendali Rantis Water Cannon sesuai kebutuhan operasional Polri. Hasil pengujian di hadapan tim Puslitbang Polri menunjukkan kemampuan pengendalian sudah sesuai dengan kebutuhan operasional Polri.Pengujian dengan 1 canon air didapatkan jarak terjauh capaian air 55 meter, dengan 2 canon air sekaligus didapat jarak 45 meter. Pada jarak 30 meter berhasilkan menjatuhkan 1 tong berisi setengah air yang ditumpuk di atas 2 tong berisi penuh air.

Kata kunci: Canon Air, Integrasi, Nozzle, Prototipe, Rantis, Sistem Kendali Water Cannon, Uji Kehandalan.

\section{PENDAHULUAN}

$\mathrm{K}$ endaraan Taktis (Rantis) Water Cannon merupakan salah satu jenis kendaraan taktis yang dimiliki oleh aparat kepolisian yang berfungsi untuk meredam aksi kekerasan dan mengamankan demonstrasi yang bersifat anarkis, dengan cara menyemprotkan air atau sejenis cairan yang dapat secara langsung membubarkan aksi huru hara tersebut ${ }^{[1]}$. Untuk meningkatkan kemandirian dalam pengadaan Rantis Water Cannon sesuai kebutuhan operasional Polri, BPPT sebagai Lembaga Pemerintah Non Kementerian (LPNK) bekerjasama dengan PT Astanita Sukses Apindo (ASA) mendapatkan dana insentif dari Kemenristekdikti untuk mengembangkan Rantis Water Cannon Nasional. Salah satu tujuan utama dari pemberian insentif ini adalah untuk meningkatkan kemampuan industri nasional dalam memproduksi Alat-alat Pertahanan Keamanan (Alpalhankam) dengan Tingkat Kandungan Dalam Negeri (TKDN) hingga 25\%. Selama 5 tahun terakhir ini produk Rantis Water Cannon Polri merupakan produk impor 100\% ${ }^{[1][2][5]}$. Setelah pada tahun 2016 kerjasama BPPT dengan PT ASA ini telah berhasil menyelesaikan sebuah prototipe sistem kendali Water Cannon, maka pada tahun 2017 dilanjutkan dengan integrasi pada Kendaraan Taktis (Rantis) Water Cannon. Setelah berhasil melakukan integrasi, maka dilanjutkan dengan pengujian statis dan dinamis, melakukan berbagai variasi tembakan dengan canon air.

\section{SISTEM KENDALI RANTIS WATER CANNON}

Sistem Kendali Rantis Water Cannon yang dikembangkan BPPT bersama PT ASA sejak tahun 2017 adalah seperti pada gambar 1 di bawah ini ${ }^{[1][5]}$.
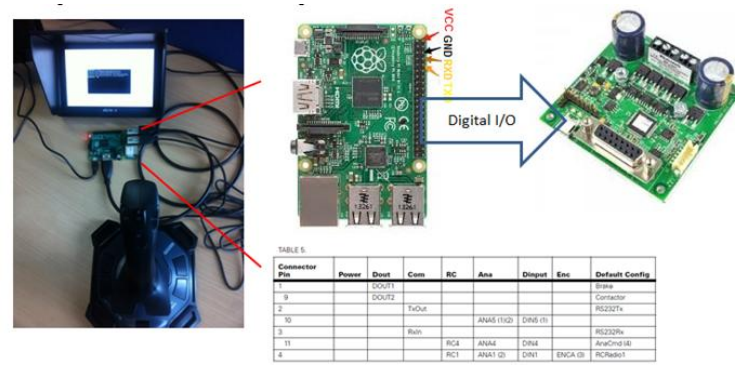

Gambar 1. Prototipe Sistem Kendali Rantis Water Cannon yang dikembangkan BPPT bersama PT ASA ${ }^{[1][5]}$.

\footnotetext{
${ }^{1}$ BPPT, Serpong Tangeran Selatan, Banten,

${ }^{2}$ PT Astanita Sukses Apindo, Cileungsi, Jawa Barat
} 
Sistem kendali Water Cannon yang dirancang ini merupakan hasil integrasi modul-modul terpisah yaitu diantaranya adalah controller raspberry pi 2, sensor thermal, motor DC actuator, display monitor, joystick, dan kamera pemantau. Seluruh komponen dikendalikan oleh controller raspberry pi 2 yang dapat mengendalikan nozzle dan proses penembakan. Seluruh data rekaman video akan disimpan pada harddisk DVR melalui perintah dari microcontroller raspberry pi 2, dapat diihat pada Gambar 2.

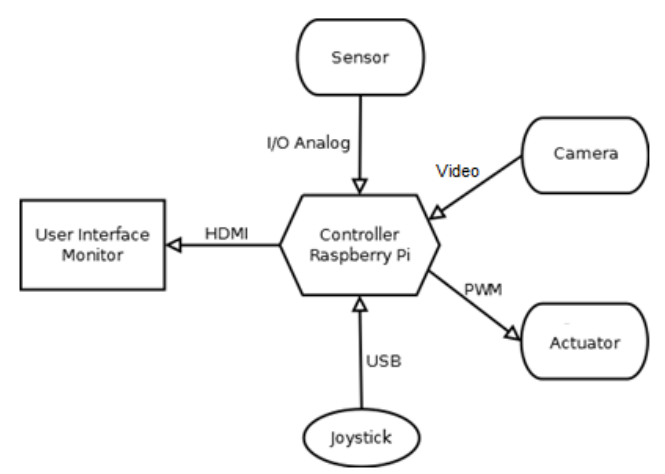

Gambar 2. Diagram Blok Sistem Kendali Water Cannon ${ }^{[1][5]}$.

\section{PENGUJIAN SISTEM KENDALI RANTIS WATER CANNON SEBELUMNYA}

Sistem kendali Water Cannon yang dirancang ini telah melalui serangkaian pengujian mandiri ${ }^{[1]}$, seperti :

1. Pengujian pembacaan data pergerakan joystick : sesuai rancangan ${ }^{[1]}$.
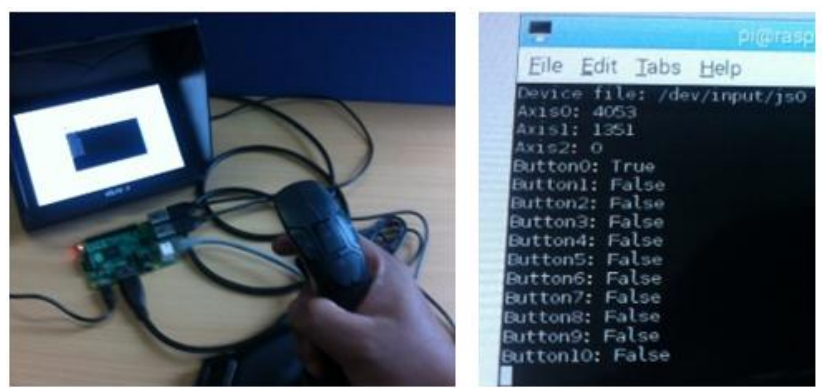

Gambar 3. Pengujian pembacaan data pergerakan ${ }^{[1]}$

2. Pengujian fungsi driver motor : sesuai rancangan ${ }^{[1]}$.
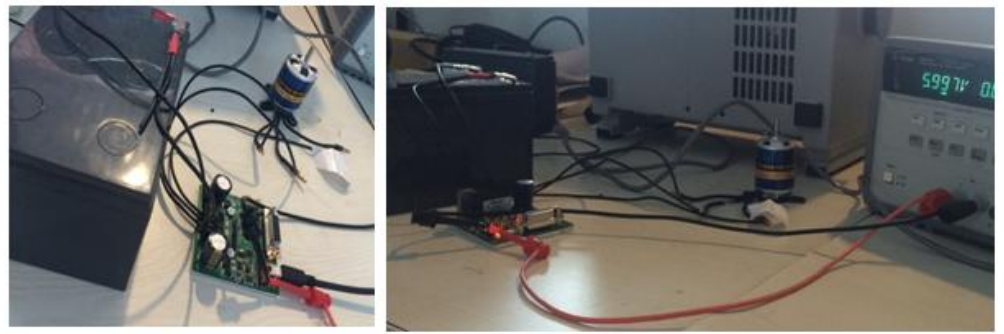

Gambar 4. Uji fungsi driver motor $^{[1]}$

3. Uji penembakan air dengan Model Rantis Water Cannon : sesuai rancangan ${ }^{[1]}$. 


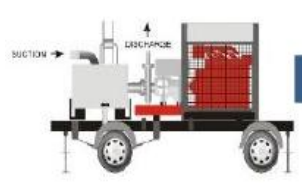

KONSEP MODEL AWAL

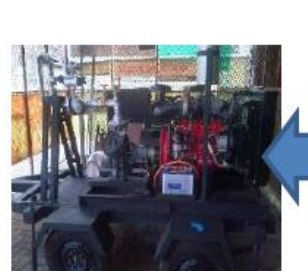

SISTEM PLUMBLING DAN DUDUKAN NOZZLE

MONITOR+SISTEM KONTROL TERPASANG DI PROTOTIPE

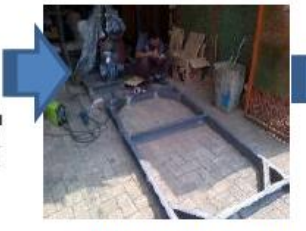

PEMBUATAN RANGKA AWAL

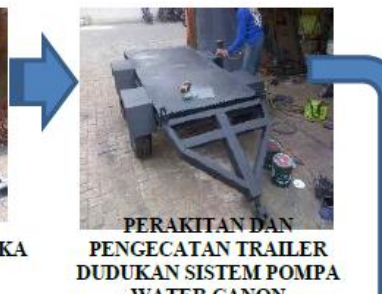

WATER CANON

Gambar 5. Sistem Pengujian Model Sistem Kendali Water Cannon ${ }^{[1]}$

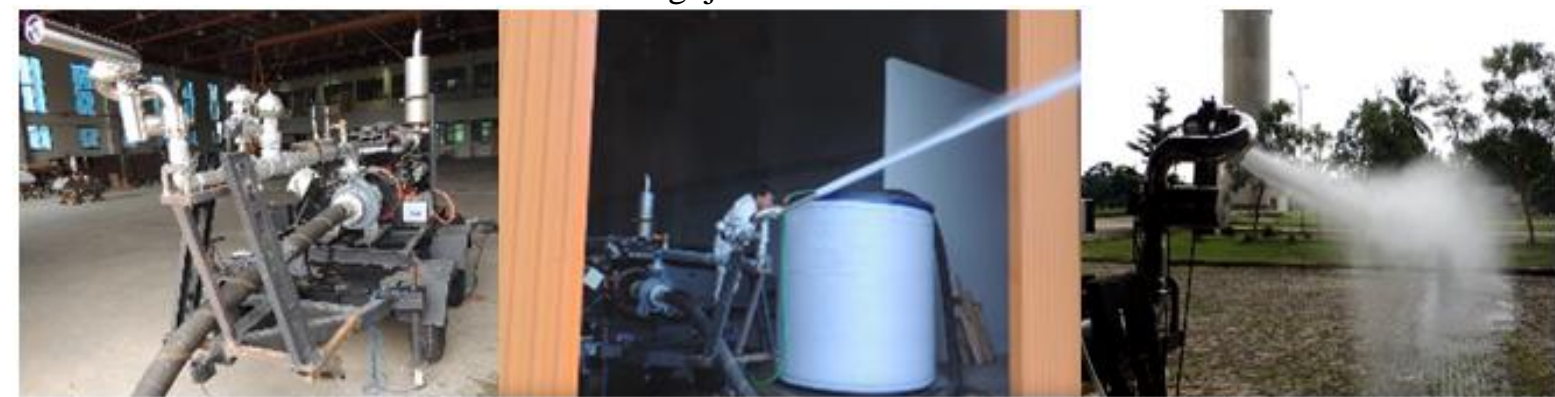

Gambar 6. Uji Penembakan Air dengan Model Sistem Kendali Water Cannon ${ }^{[1]}$

\section{MODIFIKASI RANTIS WATER CANNON OLEH PT ASTANITA}

Dengan dana Insentif PPTI Kemenristekdikti tahun 2017, PT ASA dengan supervisi dari tim BPPT telah melakukan modifikasi truk Hino PT ASA menjadi Rantis Water Canon, seperti pada gambar 7-8 di bawah ini.

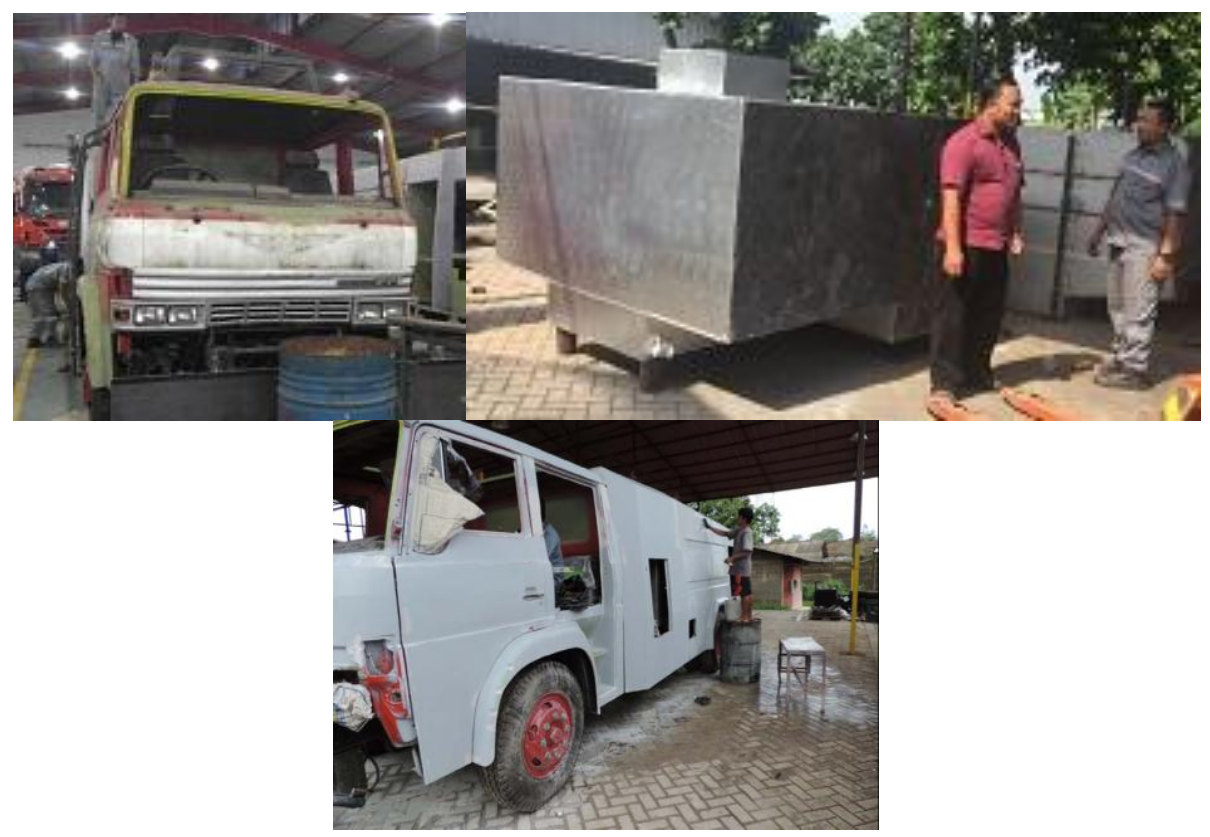

Gambar 7. Modifikasi Sistem Kendaraan dan Tangki Air.

Kendaraan Rantis Water Canon ini merupakan modifikasi dari truk angkutan barang milik PT ASA yang dilepas bak pengangkutnya, lalu dimuati dengan tangki air berkapasitas 3500 liter, yang sebelumnya dibuat terpisah di luar kendaraan. Modifikasi lain yang dilakukan adalah pembuatan kabin kedua dibelakang kabin pengemudi dengan cara memundurkan batas kepala kabin truk dan menambah pintu kiri kanan untuk kabin kedua tersebut. 

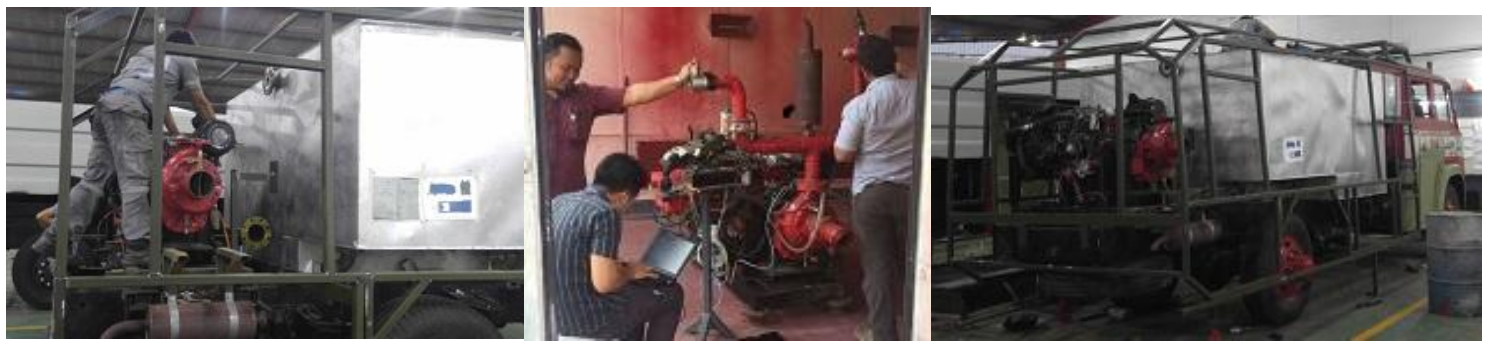

Gambar 8. Integrasi Sistem Pompa pada Sistem Kendaraan

Di belakang tangki air berkapasitas 3500 liter dipasang sistem pompa agar titik berat kendaraan saat air penuh ataupun kosong tidak berubah dratis yang bisa mengakibatkan truk tidak bisa menanjak dan sebagainya. Seperti terlihat pada gambar $8 \mathrm{di}$ atas, setelah tangki air dan pompa terpasang maka dibuat rangka besi untuk meletakkan plat besi sebagai bodi kendaraan sesuai desain yang dibuat sebelumnya.

\section{INTEGRASI SISTEM KENDALI PADA RANTIS WATER CANNON}

Dengan dana Insentif PPTI Kemenristekdikti tahun 2017, tim BPPT dibantu tim PT ASA telah memasang Prototipe Sistem Kendali dan perlengkapan lainnya pada Rantis Water Canon, seperti pada gambar 9-11 di bawah ini.
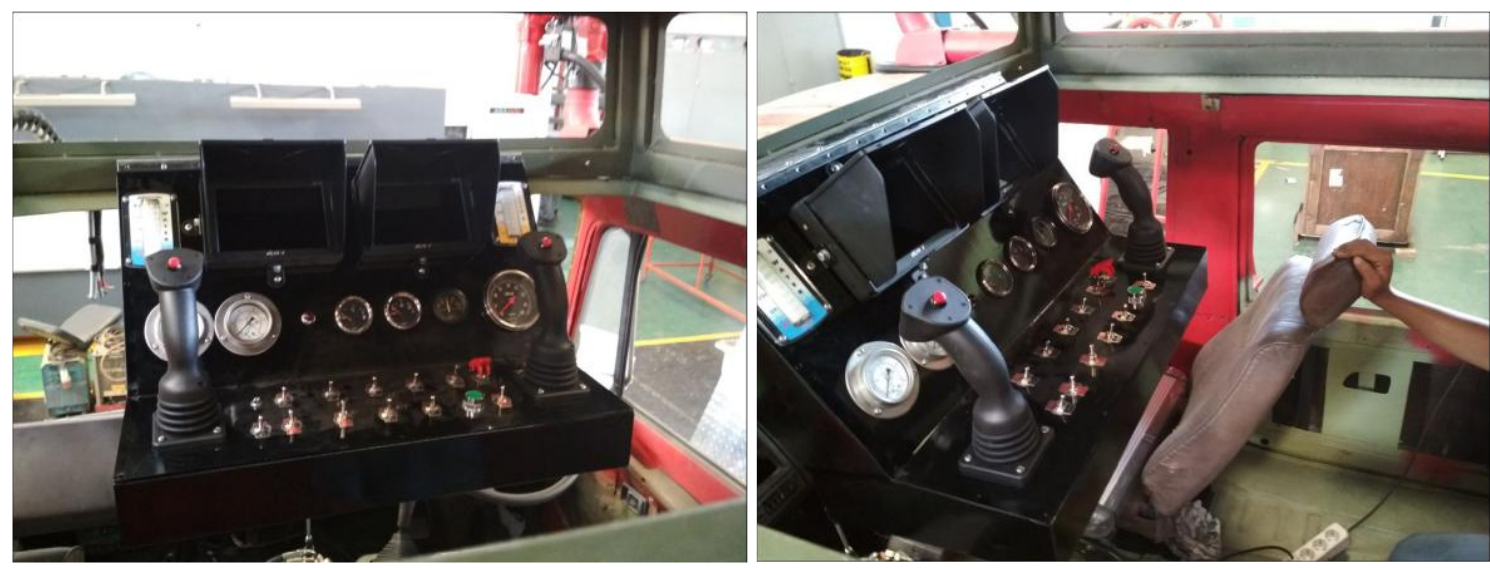

Gambar 9. Integrasi Sistem Kendali pada Sistem Kendaraan

Panel sistem kendali seperti pada gambar 9 di atas dipasang pada kabin kedua dibelakang pengemudi / komandan kendaraan Rantis ini. Pada Rantis ini Panel sistem kendali seperti pada gambar 9 dapat dioperasikan oleh seorang operator dengan menggunakan tangan kiri dan tangan kanannya. Bila akan digunakan oleh 2 orang operator. maka dapat dilakukan dengan menambah 1 kursi operator, dengan menggeser sedikit kursi operator yang pertama.
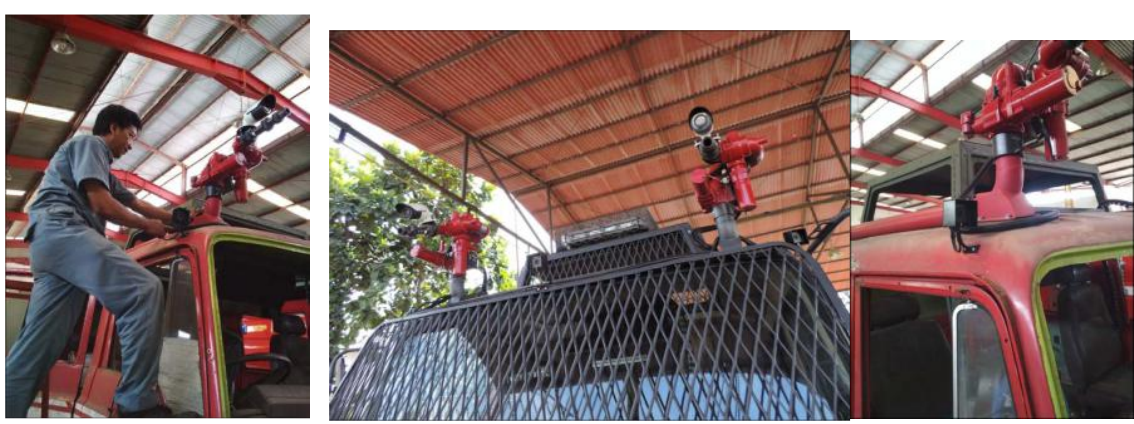

Gambar 10. Integrasi Sistem Nozzle pada Sistem Kendaraan

Sistem Nozzle dipasang di kiri kanan atap kabin depan yang dapat dioperasikan secara terpisah 
Eko Syamsuddin Hasrito, Dede Santoso, Kuwat Darmanto dan Agustian (independent) dan dilengkapi dengan kamera yang dapat di monitor di panel kendali di kabin kedua. Di dashboard kabin depan di pasang kamera dan monitor yang mengarah ke depan, biasanya untuk merekam wajah para pemimpin demonstrasi atau para provokator untuk bukti-bukti demonstrasi nantinya.
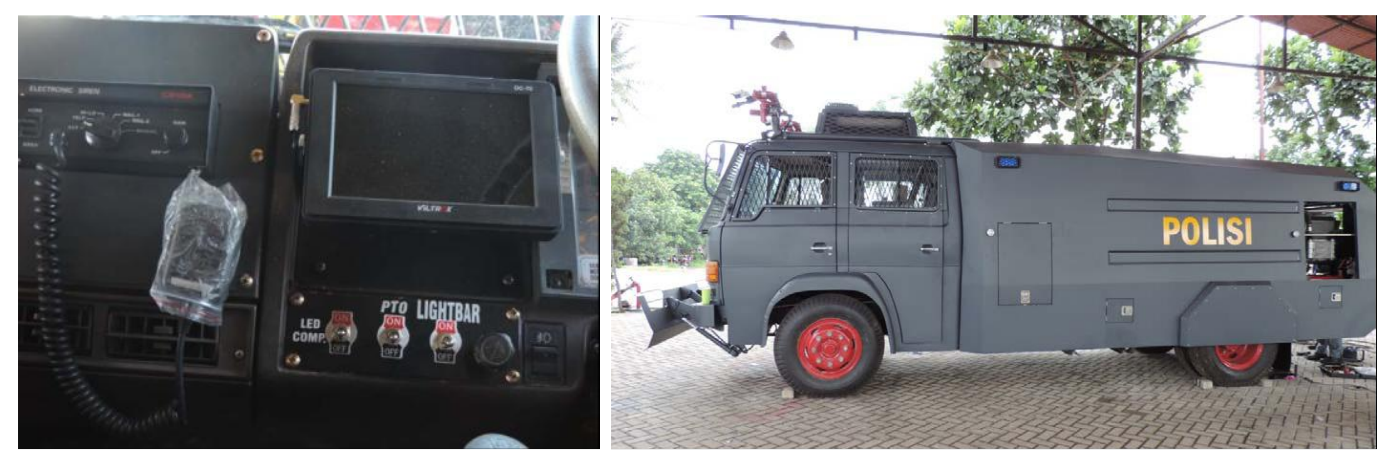

Gambar 11. Integrasi Sistem Kamera dan Sistem Kendaraan Water Canon sudah siap

\section{PENGUJIAN SISTEM KENDALI PADA RANTIS WATER CANNON}

Pada akhir tahun 2017, tim BPPT dibantu tim PT ASA telah menguji Sistem Kendali Rantis Water Canon dihadapan tim Puslitbang Polri, seperti pada gambar 12-13 di bawah ini.
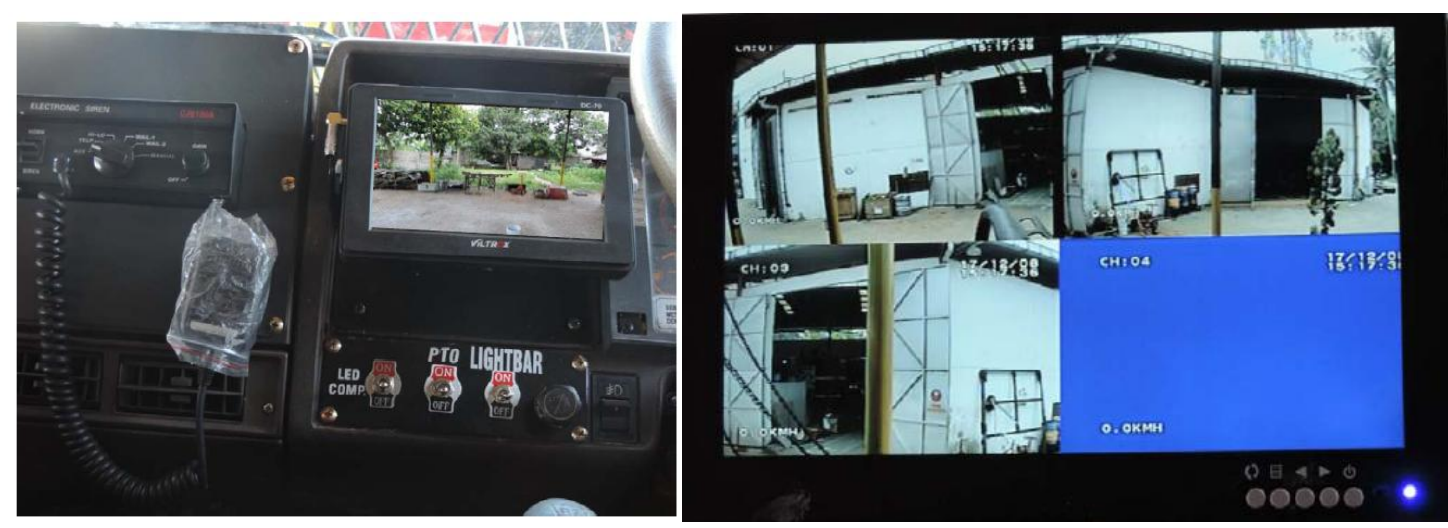

Gambar 12. Pengujian Sistem Kamera

Gambar 12 menunjukkan hasil pengujian kamera depan dan kamera belakang untuk memonitor sekeliling kendaraan Rantis Water Canon. Sedangkan Gambar 13 menunjukkan foto-foto saat pengujian dengan canon air baik dari canon kiri atas maupun canon kanan atas.

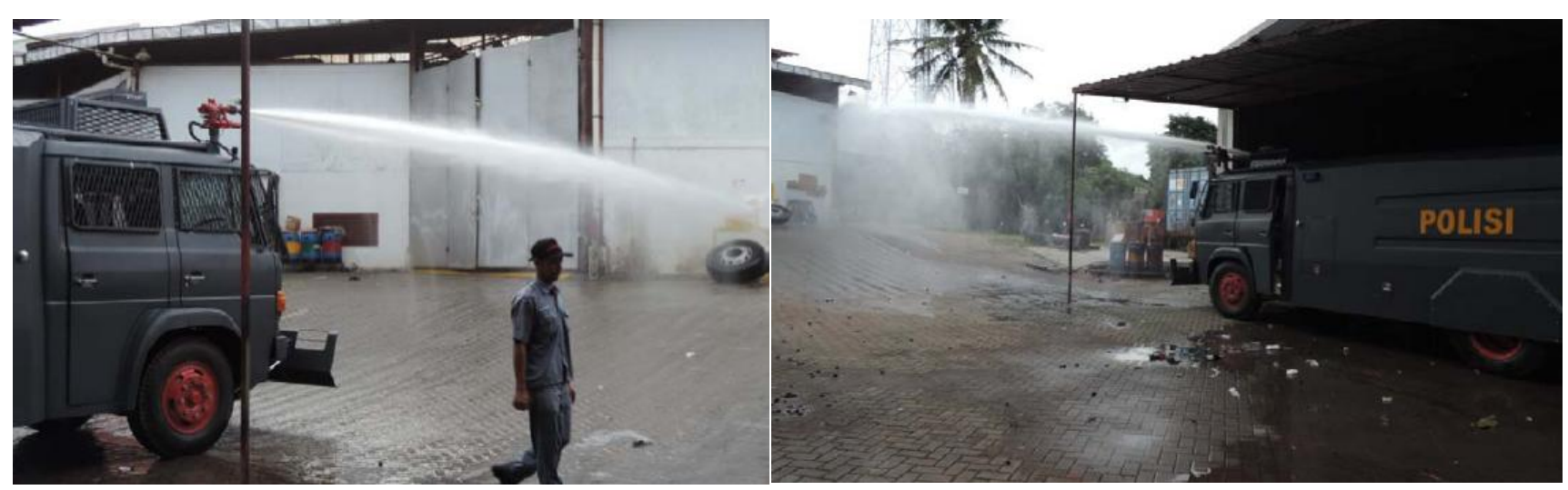

Gambar 13. Pengujian Sistem Kendali Water Canon 
Integrasi Dan Pengujian Prototipe Sistem Kendali Pada Kendaraan Taktis Water Cannon Sesuai Kebutuhan Polri

\begin{tabular}{|c|c|c|c|c|c|c|c|}
\hline \multirow{2}{*}{$\begin{array}{c}\text { Waktu } \\
\text { ( Menit ke) }\end{array}$} & \multicolumn{4}{|c|}{ POMPA } & \multicolumn{2}{|c|}{ MESIN } & \multirow[b]{2}{*}{ KETERANGAN } \\
\hline & $\begin{array}{c}\text { Kapasitas } \\
(\mathrm{gpm})\end{array}$ & $\begin{array}{c}\text { Tekanan } \\
\text { buang } \\
\text { ( bar) }\end{array}$ & $\begin{array}{l}\text { Tekanan hisap } \\
\text { ( in. } \mathrm{Hg} \text { ) }\end{array}$ & $\begin{array}{l}\text { Putaran } \\
\text { pompa } \\
(\mathrm{rpm})\end{array}$ & $\begin{array}{l}\text { Temperatur } \\
\left({ }^{\circ} \mathrm{C}\right)\end{array}$ & $\begin{array}{c}\text { Putaran } \\
\text { mesin } \\
(\mathrm{rpm})\end{array}$ & \\
\hline 0 & 750 & 10 & $-17,5$ & 3.981 & 75 & 2118 & \\
\hline 5 & 750 & 10 & $-17,4$ & 3.978 & 75 & 2116 & \\
\hline 10 & 750 & 10 & $-17,6$ & 3.983 & 80 & 2119 & \\
\hline 15 & 750 & 10 & $-17,5$ & 3.981 & 85 & 2118 & \\
\hline 20 & 750 & 10 & $-17,4$ & 3.983 & 85 & 2119 & \\
\hline
\end{tabular}

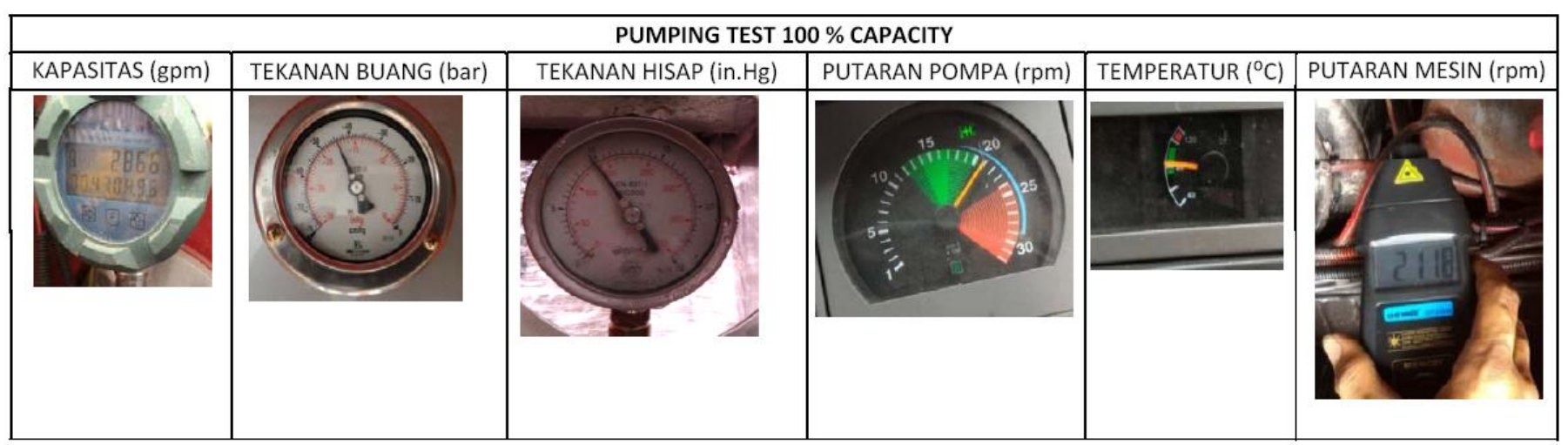

Gambar 14. Hasil Pengujian Sistem Kendali Pompa Water Canon

Gambar 14 menunjukkan hasil pengujian dengan canon air dan hubungannya dengan kemampuan dan kestabilan sistem pompa. Begitu pula Tabel 1 menunjukkan konsistensi dari 3 kali pengujian dengan tekanan awal 15 bar, ada selisih Rpm yang masih dalam batas toleransi.

Tabel 1. Hasil Pengujian dengan Tekanan 15 Bar dengan 3 Variasi Rpm

\begin{tabular}{|l|c|c|c|}
\hline \multicolumn{1}{|c|}{ Parameter Uji } & Uji 1 & Uji 2 & Uji 3 \\
\hline Jarak Semprotan (m) & 10 & 10 & 10 \\
\hline Tekanan Hisap (in.Hg) & -20.5 & -20.7 & -20.8 \\
\hline Besar Tekanan (bar) & 15 & 15 & 15 \\
\hline Tekanan Kerja Air & 80 & 80 & 80 \\
\hline Temperatur $\left({ }^{0}\right.$ C) & 86 & 85 & 84 \\
\hline Putaran Mesin $($ Rpm) & 2354 & 2355 & 2356 \\
\hline
\end{tabular}




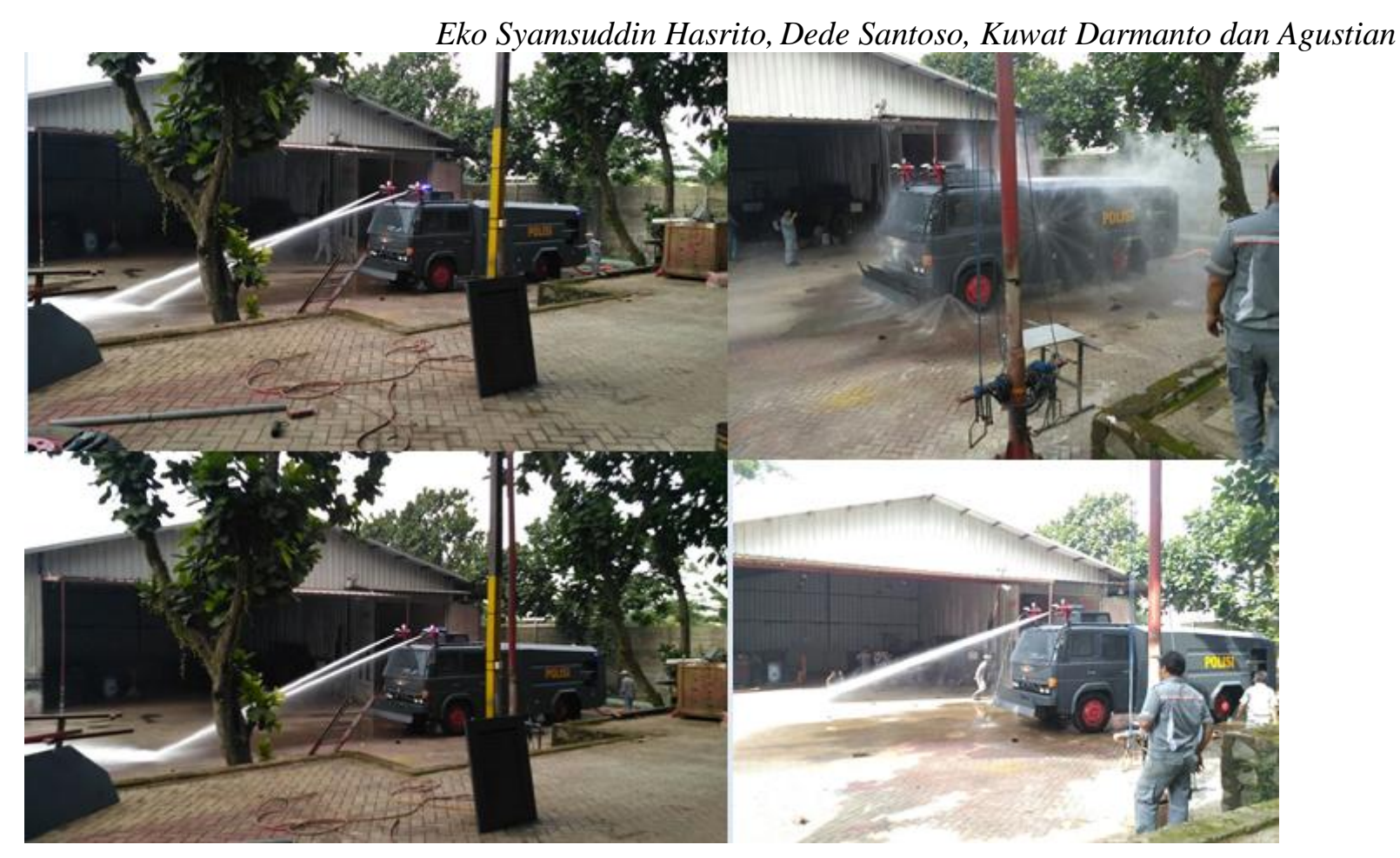

Gambar 15. Hasil Pengujian Sistem Kendali Pompa Water Canon dengan variasi 2 canon, 1 canon

dan self protection (pengamanan kendaraan dari lemparan bom Molotov, dan sebagainya)

Gambar 15 menunjukkan foto-foto Pengujian Sistem Kendali Pompa Water Canon dengan variasi 2 canon, 1 canon dan self protection (pengamanan kendaraan dari lemparan bom Molotov, dan sebagainya). Untuk self protection sekeliling bodi kendaraan dipasangi 8-10 sprinkle.

Pada tanggal 15 Februari 2018, tim BPPT dibantu dengan tim PT Astanita dan disaksikan oleh tim Puslitbang Polri melakukan pengujian akhir dengan mengukur jarak terjauh dengan 1 canon, 2 canon dan kemampuannya untuk menjatuhkan tong berisi air setengah kapasitas yang ditumpuk diatas 2 tong lain dengan kapasitas penuh, sesuai standard pengujian Puslitbang Polri.

Tabel 2. Hasil Pengujian dengan 1 canon, 2 canon dan tong bertumpuk

\begin{tabular}{|c|c|c|c|c|}
\hline No & $\begin{array}{c}\text { Jarak Tembak } \\
(\text { Meter })\end{array}$ & $\begin{array}{c}\text { Tekanan } \\
\text { Pompa (Bar) }\end{array}$ & $\begin{array}{c}\text { Kekuatan Tembak } \\
(\text { KgF })\end{array}$ & Keterangan \\
\hline 1 & 55 & 15 & - & Jarak tembak terjauh 1 canon \\
\hline 2 & 45 & 15 & - & Jarak tembak terjauh 2 canon \\
\hline 3 & 35 & 15 & 28.86 & Tong tidak jatuh \\
\hline 4 & 30 & 15 & 39.74 & Tong jatuh \\
\hline
\end{tabular}

Sedangkan pada tanggal 5 Maret 2018, mitra PT Astanita telah menerima tim BPK dalam kegiatan pemeriksaan fisik hasil pekerjaan Insentif PPTI Water Canon Vehicle. Pada hari itu juga dilakukan demonstrasi kepada tim Puslitbang Polri dan menyatakan hasil pengujian dapat memenuhi standard operasional Polri. 


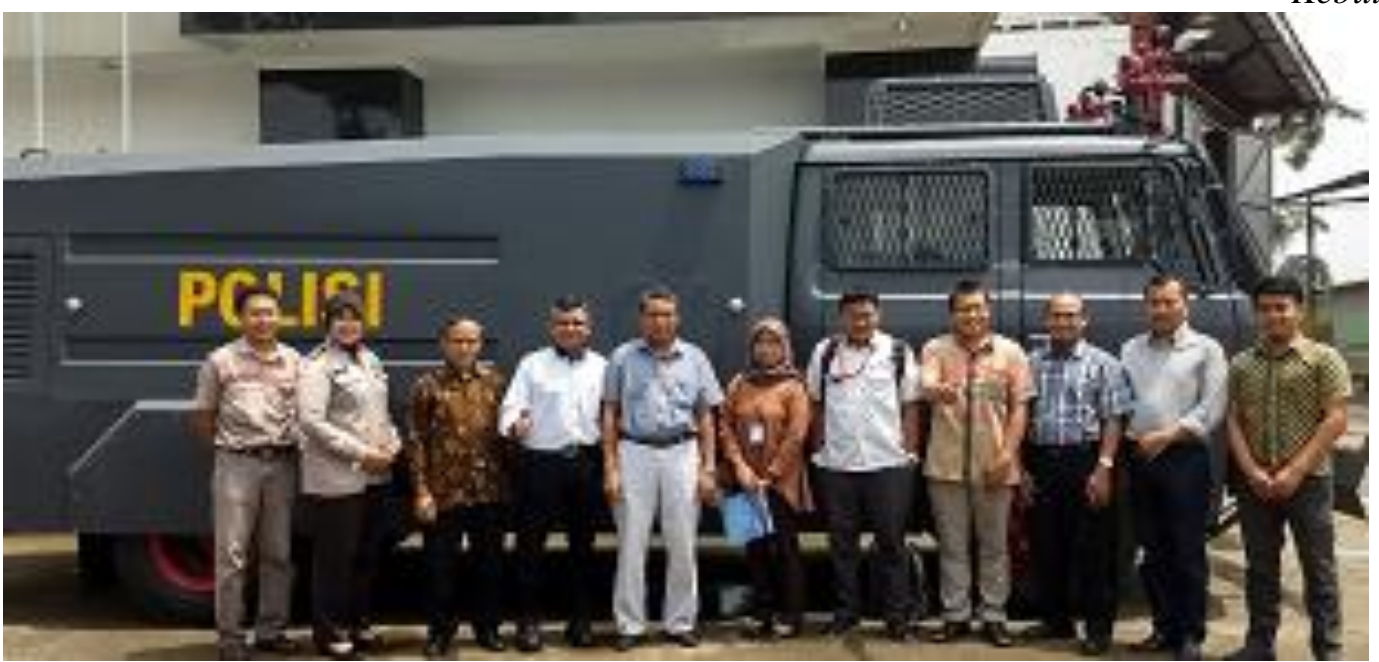

Gambar 16. Foto setelah pengujian dihadapan BPK dan Puslitbang Polri [5 Maret 2018]

\section{KESIMPULAN}

Pengembangan sistem kendali Water Cannon telah dapat dibuktikan kemampuannya dengan terlebih dahulu mengintegrasikannya pada kendaraan Rantis dan melakukan pengujian-pengujian baik uji statis maupun uji dinamis. Dari pengujian dengan tim Puslitbang Polri didapatkan hasil telah sesuai dengan standard operasional Rantis Water Cannon Polri. Prototipe sistem kendali pada Rantis Water Cannon ini dapat dijadikan acuan pengembangan selanjutnya oleh industri dalam negeri, guna lebih meningkatkan nilai TKDN dari Rantis Water Cannon Polri sehingga dapat lebih meningkatkan kemandirian bangsa.

\section{DAFTAR PUSTAKA}

[1] W. Cesar, E.H. Syamsuddin, Perancangan Model Sistem Kendali Kendaraan Water Cannon Berbasis Microcontroller Raspberry Pi, Jurnal Tesla, Universitas Tarumanagara, Vol.18, No.1, Maret 2016.

[2] E. H. Syamsuddin, H. Ilham, Kesiapan Industri Nasional dalam mendukung Peningkatan TKDN Almatsus-Polri, Prosiding Seminar Teknologi Hankam 2014, Puspiptek-Serpong, BPP Teknologi, 2014.

[3] Surat Keputusan Kapolri No. SKEP/360/VI/2005, Tentang Grand Strategi Polri 2005-2025.

[4] Surat Keputusan Kapolri No. KEP/53/I/2010, Tentang Rencana Strategis Polri 2010-2014.

[5] PTIPK-BPPT, Program Document (Laporan Akhir) Kegiatan Inovasi dan Layanan Teknologi Kendaraan Taktis, Kendaraan Tempur dan Munisi Kaliber Besar, BPP Teknologi, Desember 2015. 